\title{
An Exploration of Inclusion of Spirituality into the Balanced Scorecard (BSC) to Support Financial Performance: A Review
}

\author{
Fahmi Fadhl Al-Hosaini ${ }^{1} \&$ Saudah Sofian ${ }^{1}$ \\ ${ }^{1}$ Department of Accounting and Finance, Faculty of Management, Universiti Teknologi Malaysia, 81310 UTM \\ Johor Bahru, Malaysia \\ Correspondence: Saudah Sofian, Department of Accounting and Finance, Faculty of Management, Universiti \\ Teknologi Malaysia, 81310 UTM Johor Bahru, Malaysia. Tel: 60-19-727-7416. E-mail: Saudah@utm.my
}

Received: December 30, 2014 Accepted: February 2, 2015 Online Published: April 2, 2015

doi:10.5539/ass.v11n9p289

URL: http://dx.doi.org/10.5539/ass.v11n9p289

\begin{abstract}
The BSC has been well accepted as a suitable tool for assessing and monitoring financial performance of organisations. Subsequently it has been embraced by organisations as financial and nonfinancial performance indicators that help organizations align their initiatives with the organization's strategy. However, the question of how the BSC can be enhanced to incorporate non-financial performance is still being raised. One of the important non-financial prospectives is the Spirituality. The goal of this paper is to review the recent research on Spirituality as nonfinancial performance indicator for the BSC. In this paper an overview of the BSC and its perspectives is given, providing a justification for the importance of non financial performance measures to overall organizational performance. The novelty of this paper is that through an elaborate discussion, Spirituality is proposed as a potential additional dimension that can enhance the BSC. Subsequently, the enhanced BSC would incorporate spirituality as an important dimension that affects employees as well employers, who are the key drivers of financial performance. Overall, the proposed dimension would strengthens the tool's efficiency and effectiveness.
\end{abstract}

Keywords: balanced scorecard, spirituality, non-financial perspective, financial performance

\section{Introduction}

Among the many performance management systems, the BSC is identified as one of those that require further research based on its previous record. It has a proven potential to influence enhancement of organisational performance and growth (Al-Zwyalif, 2012; Chen, Lee, \& Mo, 2012; Li, 2011). In line with this, Kaplan (2012) makes important and insightful comments on BSC and strategy implementation while arguing against the usual academic commentaries of some experts on BSC; who often ignore its role in strategy execution.

The BSC was introduced in 1990 by Kaplan and Norton as a systematic tool for performance improvement of organisations, away from the classical methods through the use of measurements and indicators. In contrast to other tools, BSC links strategy of the organisations with their performance and this is usually done beyond determining the traditional financial measurement in the success of organisations. The BSC is based on four perspectives of performance measures, which are financial, customer, internal business processes, and learning and growth (Kaplan \& Norton, 1996a; Kaplan \& Norton, 1992; Niven, 2005).

It highlights the business processes, determinants of business success, as well as cause and effect relationships in relation to business strategy. It is primarily utilized as a tool to bring about formulation of strategy, its realization as well as its communication. Additionally, it also helps in keeping track of performance and in providing assessment feedback. The BSC system facilitates sustained focus and attention towards strategic initiatives and continuous review.

Besides the above, BSC's researchers have investigated various factors that drive organisational performance. One area that has not been given as much attention is the contribution of non-financial factors to overall organizational performance (Karun \& Pilaipan, 2011).

Other studies suggested that spirituality can also play a vital role if it is incorporated in BSC (Fry, Matherly, \& Ouimet, 2010; Pratoom \& Cheangphaisarn, 2011; Ramli, 2006). Among them, Ramli (2006) developed BSC concepts from Islamic perspective tagged as the Hadhari scorecard. He considers Hadhari scorecard as a 
civilisation that promotes both material and the non-material (humane and spiritual) aspects of improvement to the classical Kaplan and Norton (1992) BSC. The author argues that the traditional BSC developed by Kaplan and Norton (1992) failed to execute the desired objectives it was designed for as documented by Kaplan and Norton (1996a). In the latter improvements in the BSC in 2004, Kaplan and Norton still mentioned that what was missing was the ability to communicate the strategy formulated to a larger workforce in organizations and addressing non-financial performance measures.

Moreover, the performance field urges for emphasis on factors such a spirituality which contribute to customer satisfaction and well-being of employees (Kaplan \& Norton, 2004; Kaplan \& Norton, 1996a; Kaplan \& Norton, 1992; Tejeda, 2014). From the non-financial measures, the employees' performance with the inclusion of leadership, arise as the core and significant indicator of performance categories (Kaplan \& Norton, 2004). The interaction of organizational performance dimensions may be complex, but leaders with strong spirituality qualities generally influence employee performance. This high performance leads to better company success and sustainability (Kaplan \& Norton, 2004).

In relation to the above, Fry, Hannah, Noel, and Walumbwa (2011) suggested that Spirituality is an important element that boosts performance. The authors provided two important reasons to justify the significance of spirituality. First, spiritual solutions are sought by the society to address social and business dynamic changes (Cash \& Gray, 2000), and second, global changes have led to social spiritual consciousness (Duchon \& Plowman, 2005; Inglehart, 1997). This is consistent with Duchon and Plowman (2005) statement which emphasises on focusing on the spirit at work so as not to ignore a basic feature of what is being human. Evidence also exists to support the notion that spirituality activities at the workplace lead to advantageous individual job satisfaction for the employees. It also enhances commitment while delivering enhanced productivity, minimized absenteeism and turnover, and the promotion of greater degrees of organisational performance (Duchon \& Plowman, 2005; Elm, 2003; Fry, 2005; Garcia-Zamor, 2003; Giacalone \& Jurkiewicz, 2003; Reder, 1982). Therefore this paper reviews the use of the Spirituality as an improvement of the in the BSC to enhance is focus on non-financial performance.

\section{The Balanced Scorecard (BSC)}

The Balanced Scorecard (BSC) is a useful tool that links strategy with performance with extended measures on how the different levels of the organization contribute to overall success. The notion of BSC is that an organization's strategies and their execution are among the most important factors in performance improvement (Rigby, 2001). The shift from an industrialized economy to information economy has called for a change in how value is determined. The scorecard enables organisations to peruse their financial results while at the same time scrutinizing their development in creating capability in obtaining insubstantial required assets for future development.

Additionally, the BSC offers management the chance to acknowledge not just how insubstantial assets may affect the financial results but also the way performance initiatives may affect the long-term strategic aims of the organisations. Thus, the process of data collection and analysis are vital ingredients, in order to generate the significant and successful impact for the organisation. This is part of the views advanced in Kaplan and Norton (1992) report.

Consequently, if the organization chooses the wrong measures, the significance of data collection may be lost. The BSC handles this issue by a planned dimensions analysis; this is achieved by rectifying influence of inaccurate actions through the introduction of a factor/measurement at any point in time. The BSC is based on the notion that both measures (financial and non-financial) of performance are combined in one ultimate scorecard. Subsequently, the proposition being made in this paper is to incorporate spiritual as another dimension of non financial performance measures so as to enhance its coverage.

\subsection{Four Perspectives of Balanced Scorecard}

The BSC framework is a tool that reveals the cause and effect scenarios in the strategic management structure for an organization in respect of the four perspectives of BSC (Kaplan \& Norton, 2001b): financial, customer, internal process and learning and growth. Part of the implications of these perspectives is the effect of the organizations' internal process as well as learning and growth innovations have on the creation of new services and products that will satisfy the needs of the customers, and enable better and prosperous financial achievements. Thus, the internal structures of an organization have a direct relationship to the outcomes that are being offered to the outside customers (Kaplan, 2004). A brief description of the various perspectives is given in the following sub-sections. 


\subsubsection{Financial Perspective}

The financial perspective is considered as the most important perspective among the others, particularly in relation to key strategy implementation and assessment of organizations' performance. Usually, it occupies the topmost part of the BSC. This is usually actualized through the provisions of the organisations' mission and vision statements and the transformation of financial issues into sustainable goals and minimal cost (Niven, 2011). The cause and effect trend can be seen through the financial index, irrespective of whether they are tangible or intangible. In addition, there should be ways by which the financial perspective can be used for raising the long-term stakeholder values, expanding the market and reducing costs.

The following measures are therefore important in ensuring cash flow, revenue, profitability, return on equity, sales growth, and market share and budget variances. Normally they are considered as lagging indicators (Kaplan \& Norton, 2005).To achieve this good assessment of all contributing units the other three perspectives are very crucial.

Furthermore, Kaplan and Norton (2004) encouraged the use of a five-step process as in the activity-based cost management, which remains a challenge in achieving organizations' operational improvements. These steps are "develop the business case, establish priorities, provide cost justification, and track the benefits and measure performance for ongoing improvement." In this way, there exist solutions for the quest of organizations' better performances, by the provisions of links between available resources and activities.

\subsubsection{Customer Perspective}

According to Kaplan and Norton (1992), there are two measurement standards. First is the "core measure group", which includes customer retention, market share, customer satisfaction, customer acquisition, and customer profitability. The next performance driver guides the organisation to the customer value proposition, and include lead times, quality, attributes of product and quality, image and relationship. It was therefore argued in Kaplan and Norton (2001b), that these will be achievable with the right choice of customers with highest value propositions. These values, according to Niven (2011), can be achieved in any of the following three ways: (i) operational excellence concentrates on reasonable price and quick response, (ii) there are turn around innovate drives by product leadership towards improving both products and services qualities of the organisation, (iii) creating an enabling customer intimacy based on long-term relationship due to vivid understanding of customer needs.

On the other hand, the assessment of nonfinancial measures with customer satisfaction was reported to show the link with future financial performance. In Ittner and Larcker (1998) it is revealed that customer behaviour and financial results are relatively constant over broad ranges of customer satisfaction levels supporting the argument in Kaplan and Norton (1996b). From the afore mentioned discussion, it is clear that there is a potential relationship between customer perspective and financial performance in organisations. Thus, customer perspective is included in this research theoretical review. This paper suggests including spirituality in the BSC framework.

\subsubsection{Internal Process Perspective}

Kaplan and Norton (2004) stated that organisations should continue to conduct innovation in products, services and internal processes for the creation of more customer value. A process of innovation guided by the needs of customers encapsulates four major processes; identification of the opportunities for new products and services, managing the R\&D portfolio, designing and developing new production and service, bringing novel products and services to the market. Hence, the internal process can be referred to as a supply chain which develops services to customers. The institution should keep on adding value to the processes in order to offer better service. The case organisation should conduct four operations; innovation process, quality service process, customer management process, and regulatory and social processes.

Bovet and Martha (2000) argued that the classic supply chain which involves the process of forecasting, purchase, manufacturing, warehousing, and distribution, no longer satisfies the dynamic and versatile market. Value-added activities should start with demand-pull. The customers should be allowed to participate in the design level and provide service. Combining the customers, suppliers and enterprise in what is called the 'value net' can turn into a fast and dynamic system that is required to satisfy needs of customers and sustain the organisation's core competitive advantage. Thus, the internal process measures of the BSC can provide early monitoring of process effectiveness and efficiency. Bearing in mind the above findings, this paper suggests that there is a potential relationship between internal process perspective and financial performance in organizations which in turn calls for attention to be given to non financial performance measures such as spirituality. 


\subsubsection{Learning and Growth Perspective}

Learning and growth are two major features that every organization's strategy should incorporate. There are different varieties of leading indicators and intangible assets that can be used to depict these features. These include (Chuang, 2007): human, information, and organisation capital, culture, alignment, and teamwork. Thus, the organization must adopt a measurement method that they want as opposed to what they can. In Kaplan and Norton (2004), the importance of this perspective in measured through the ability of organisational capital, employees, and knowledge systems on one hand, as well as their importance in communicating value creations to the organisations on the other.

Human capital attempts to emphasize the investment on the employees who are responsible for critical internal processes to achieve an extraordinary level. The information capital backs up the infrastructure and strategic to assist the performance of human capital. The four elements of organisational capital namely culture, alignment, leadership, and teamwork facilitate and transform the behaviour of a successful organisation that is focused on strategy (Kaplan \& Norton, 2004).

According to Park and Gagnon (2006), the learning and growth perspective (organization's employees, infrastructures, and environment, and reflects employee satisfaction, motivation, empowerment, and the capabilities of employees and information systems) are argued to facilitate the performance of the other three perspectives. Whereas, the model used by Bento, Regina Bento, and Lourdes Ferreira White (2012) showed the influence of the financial dimension on the other three perspectives, it is always being directly affected by continuous improvements.

In addition, Kaplan and Norton (2001a) considered the learning and growth perspective to be related to the organisations' internal skills and capabilities. Furthermore, the following are parts of the expected possible interactions between this perspective and others: (i) learning and growth perspective's relationship to internal business process; (ii) internal business perspective to customer perspective; (iii) customer perspective to financial perspective; and (iv) employee learning and growth perspective to customer perspective.

According to Glaveli and Karassavidou (2011); Bento et al. (2012), there is evidence in management literature that supports the fact that the learning and growth perspective may lead to better financial results. Likewise, Cohen, Thiraios, and Kandilorou (2008) found that a direct relationship between learning and growth perspective on the financial perspective was established through a study involving 90 Greek companies; as well as a significant and positive relationship between learning and growth perspective and the internal perspective that will eventually affect the customer perspective. Also, in Bento et al. (2012), one of the hypotheses tested between learning and growth perspective with respect to the financial perspective shows that the learning and growth perspective had the weakest direct, positive impact on the financial perspective.

To recapitulate, it is argued that there is a potential relationship between learning and growth perspective and financial performance in organizations. Thus, it is included in this theoretical review, as such in this paper we argue that non financial performance measures, such as spirituality can add value to the BSC tool.

\subsection{The Importance of Spirituality as a New Non-financial Perspective for the BSC}

Spirituality has been identified as a key construct that can influence many core activities of institutions. The spirit of the person is a significant aspect or a driving force that is believed to be an intangible, life affirming force in all human beings. It refers to striving for values and beliefs transcending the physical world. Workplace spirituality is defined as a workplace that recognizes that employees have an inner life that nourishes and is nourished by meaningful work that takes place in the context of the community (Ashmos \& Duchon, 2000). Spirituality is based on three important components: inner life, meaningful work, and community (Duchon and Plowman (2005). It can also be described as 'a framework of organizational values evidenced in the culture that promotes employees' experience of transcendence through the work process, facilitating their sense of being connected to others in a way that provides feelings of completeness and joy (Fry et al., 2011).

A review of literature pertaining to the effects of spirituality on improving employees' performances and organizational effectiveness suggested the need to incorporate spirituality in organizations based on the following three different perspectives: (i) spirituality enhances employees' well-being and quality of life; (ii) spirituality provides employees a sense of purpose and meaning at work; (iii) spirituality provides employees a sense of interconnectedness and community. It was concluded that there is a complex paradigm shift in organizational sciences, management theory and practice in the past two decades. The influence of spirituality on employees' performances and organizational effectiveness, as well as organizational productivity or profitability has been considered to be complex in nature (Karakas, 2010). This complexity is also reflected in terms of 
definitions of spirituality at work by other researchers. For instance, Fry et al. (2010), considered the incorporation of the spirituality perspective as a necessary driver to employees' well-being, organizational commitment and productivity, corporate social responsibility and, ultimately, financial performance of the organization. Subsequently, spirituality can play an important role in enhancing the performance of organisations which may have been experiencing some problems in performance as indicated earlier.

\section{Spirituality Perspectives}

According to Fry et al. (2011), the key principle that is described as intangible, life affirming energy in an individual and for that fact, all human beings, is a person's spirit (Anderson, 2000). It underlies striving for values and beliefs that go over physical existence (Maddock \& Fulton, 1998). Workplace spirituality according to Ashmos and Duchon (2000) is defined as a workplace that recognizes that employees have an inner life that nourishes and is nourished by meaningful work that takes place in the context of community. Giacalone and Jurkiewicz (2003) defined workplace spirituality as "a framework of organizational values evidenced in the culture that promotes employees' experience of transcendence through the work process, facilitating their sense of being connected to others in a way that provides feelings of completeness and joy". There are also a number of other definitions, e.g. by Giacalone and Jurkiewicz (2003); Duchon and Plowman (2005).

In Karakas (2010), a review of about 140 articles about the effects of spirituality on improving employees' performances and organizational effectiveness was conducted based on the following three different perspectives that were introduced: (i) spirituality enhances employee well-being and quality of life; (ii) spirituality provides employees a sense of purpose and meaning at work; (iii) spirituality provides employees a sense of interconnectedness and community. It was concluded that there is a complex paradigm shift in organizational sciences, management theory and practice in the past two decades according to some researchers, e.g. (Capra, 1996; Conger \& Kanungo, 1988; Dooley, 1997; Giacalone \& Eylon, 2000; Harman \& Hormann, 1990; House \& Shamir, 1993; Lewin, 1992; Ray \& Rinzler, 1993; Wheatley, 1992).

Thus, this paradigm shift has different effects and accomplishments on the organisations in different ways. For instance, there are flexible work arrangements for employees (Gottlieb, Kelloway, \& Barham, 1998) and telecommuting (Kugelmass, 1995) as well increased focus on strategies of empowerment (Conger \& Kanungo, 1988). This is done so as to allow employees' better involvement and participation (Cotton, 1993; Hyman \& Mason, 1995), in the organisations. Accordingly, Karakas (2010) stated that this paradigm shift is innovative in nature, since it aims at mind-enriching, heart-fulfilling, and spirit-growing for employees, despite being financially rewarding.

Over the years, there have been new trends of thoughts among researchers about this paradigm shift, as well as the effects of spirituality of employees' performance and effectiveness. This is in addition to its being evident in many establishments, e.g. (Ashmos \& Duchon, 2000; Burack, 1999; Cavanagh, 1999; Duchon \& Plowman, 2005; Fry et al., 2011; Fry et al., 2010; Giacalone \& Jurkiewicz, 2003; Gogoi, 2005; Howard, 2002; Konz \& Ryan, 1999; Mitroff \& Denton, 1999; Tischler, 1999; Wagner-Marsh \& Conley, 1999).

There are also authors that referred to it as being a kind of a megatrend or 'a spiritual awakening (Fry et al., 2011; Garcia-Zamor, 2003) that is geared towards enhancing employees' well-being, sustainability and social responsibility without sacrificing performance (Fry et al., 2011). In relation to the above, Fry et al. (2011) investigated the critical link between spiritual leadership and their influence on moral and character development, as well implications the involved. This study portrayed the strong evidence for the background information on workplace spirituality, religion versus spirituality; as well as, spiritual leadership theory, involving: spiritual leading versus spiritual leadership; the emergence and unit level of analysis; and the dimensions of spiritual leadership. Others include spiritual well-being, as well as the mediating role of spiritual well-being.

Fry et al. (2011), in proffering reasons for the question posed thus: there are 'many questions why this interest in spirituality is occurring'. They gave two reasons in their statement, as follows: Firstly, society requires spiritual solutions to handle dynamic changes in society and business (Cash \& Gray, 2000). Secondly, the proposition that the global changes have brought a growing social spiritual consciousness (Duchon \& Plowman, 2005; Inglehart, 1997). Indeed, Duchon and Plowman (2005) contended the oversight of spirit at work that may translate to overlooking a basic feature of what it is to be a human being.

Thus, these review by these authors revealed an evidence to support the view that programs organised for workplace spirituality not only have beneficial results like increased joy, peace, serenity, satisfaction and commitment in the job, but also offer improved productivity, decreased absenteeism and turnover, and promote higher degrees of organisational performance (Brophy, 2014; Duchon \& Plowman, 2005; Elm, 2003; Fry, 2005; Garcia-Zamor, 2003; Giacalone \& Jurkiewicz, 2003; Reder, 1982). 
In addition, it is also imperative to distinguish spirituality from religion, despite their interconnectivities. According to Fry et al. (2011), religion is described as a theological system of beliefs, ritual, prayers, rites and ceremonies and relevant formalized ideas and practices while spirituality is the qualities of the human spirit including positive psychological concepts including love and compassion, patience, tolerance, forgiveness, contentment, personal responsibility and a harmonious relationship with the surroundings. Besides, spirituality is the seeking for a vision of service to others, through humility (by regarding oneself as an equal, and not a greater individual), through charity or love and through veracity which goes beyond the fundamental truth-telling to use ones capability of seeing things in their actual sense and hence minimising subjective bias. This perspective shows spirituality as necessary for religion but not vise versa. As a result, workplace spirituality can include or exclude religious theory and practice.

In addition, Fry et al. (2010), presented the general model of Spiritual Leadership Balanced Scorecard Business Model to have two types of spiritual leadership that requires:

1. An organizational vision, in which leaders and followers experience a sense of calling so their lives to have purpose, meaning and to make a difference.

2. An organizational culture, based on the values of altruistic love so that leaders and followers have a sense of membership, belonging, feeling understood and appreciated, and to have genuine care, concern, and appreciation for both self and others.

Based on the above discussion, it is interesting to investigate the relationship between the spirituality perspective and the resulting level of financial and non-financial performance in organizations.

\section{Relationship between Spirituality and BSC Perspectives}

The BSC concepts from an Islamic point of view were developed by Ramli (2006) and were eventually tagged as the Hadhari scorecard. According to him, the Hadhari scorecard is a civilisation promoting material and non-material elements of improvements to the classical Kaplan and Norton (1992) BSC. He added that the classical BSC does not live up to the objectives created by the authors (Kaplan \& Norton, 1996a). The improvements made in 1994, stressed that the missing element in the BSC is its ability to communicate strategy created to a more extensive workforce in the organisation.

In the performance field, an extensive focus is made by addressing the significance of non-financial predictors of financial performance like customer satisfaction, operating/internal measures, quality, leadership, innovation, and employee well-being and growth (Kaplan \& Norton, 2004; Kaplan \& Norton, 1996a; Kaplan \& Norton, 1992). This opens the discussion on other non financial determinants of performance, such as spirituality.

From the non-financial measures, the employees' performance (including leadership) turned out to be the significant indicator of other performance categories (Kaplan \& Norton, 2004). Despite the complexity of the inter-linkage of the organisational performance dimensions, generally, leaders influence high degrees of employee performance resulting in superior operations which in turn, results in higher degrees of customer satisfaction. Eventually, customer satisfaction translates to superior financial performance. As employee performance in the organisation, in all levels, is core to the effective and efficient internal operations, customer satisfaction, and eventually financial performance, a focus on employee performance is called for in organisations wishing to be successful (Kaplan \& Norton, 2004).

In Karakas (2010), a review on how spirituality supports organizational performance as well as improved employees' performances and organizational effectiveness was carried out. The authors called for the incorporation of spirituality in a positive way in organisations. Furthermore, Fry et al. (2010) considered the incorporation of the spirituality perspective as a necessary driver to employees' well-being, organizational commitment and productivity, CSR and, ultimately, financial performance of the organization.

The reviews in Dent, Higgins, and Wharff (2005); Karakas (2010), showed that there exists two school of thoughts among researchers in relation to the perception of spirituality and organizational performance. Thus, 'spirituality' is being viewed as both anti-materialist (Lips-Wiersma, 2003); and anti-positivist (Dean, Fornaciari, \& McGee, 2003). Part of the arguments in these studies is the fact that anti-materialist spirituality aspects necessitates the need for investigate studies that is aimed at establishing their relationship with financial performance (Dean et al., 2003; Dent et al., 2005; Fornaciari \& Dean, 2001).

Other studies also highlighted concerns regarding spirituality being utilized as an administrative tool to manage employees (Brown, 2003; Cavanagh \& Bandsuch, 2002; Fernando, 2005; Mirvis, 1997). According to these scholars, spirituality should be considered as an end and should not be utilized as a tool of management to maximise financial performance of organisations (Cavanagh \& Bandsuch, 2002; Fernando, 2005). In fact, some 
other scholars stressed the need for caution when it comes to the potential abuses or misuses of work spirituality (Brown, 2003; Cavanagh \& Bandsuch, 2002; Mitroff \& Denton, 1999). Contrastingly, some scholars contended that spirituality can be utilised to enhance the performance of the organisation (Ashmos \& Duchon, 2000; Fry, 2005; Garcia - Zamor, 2003; Giacalone \& Jurkiewicz, 2003); and study dedicated to spirituality should present the links between spirituality and productivity and profitability (Ashmos \& Duchon, 2000; Giacalone, Jurkiewicz, \& Fry, 2005; Giacalone \& Jurkiewicz, 2003). Researchers including Giacalone et al. (2005) called for the empirical and rigorous demonstration of the positive impacts of spirituality on work performance. The primary aim behind this contention is to legitimise the studies in the area of spirituality at work in the context of organisations. It has been recommended that spirituality experiences that are encouraged led to improved performance and profitability of the organisation (Biberman \& Whitty, 1997; Biberman, Whitty, \& Robbins, 1999; Burack, 1999; Korac-Kakabadse, Kouzmin, \& Kakabadse, 2002; Kriger \& Hanson, 1999; Neck \& Milliman, 1994; Thompson, 2000). In the past decade, increasing research projects have been carried out only to conclude the existence of a positive link between work spirituality and organisational productivity and performance (Bierly III, Kessler, \& Christensen, 2000; Delbecq, 1999; Korac-Kakabadse et al., 2002; Mitroff \& Denton, 1999). Other studies show that organisations having voluntary spirituality programs report better profits and success (Dehler \& Welsh, 1994; Konz \& Ryan, 1999; Mitroff \& Denton, 1999; Turner, 1999).

Ashmos and Duchon (2000) found that work unit performance is positively related to work unit spirituality. In support of spiritual leadership theory, there are investigations Fry (2003); Fry (2005) that show that (i) work unit spirituality can be linked with the ability of the leaders to allow the worker's sense of meaningful work (meaning/calling) and community (membership); (ii) workplace spirituality is also linked to leader's ability to be concern with unit worker's inner life/spiritual practice; for instance, immersing one's self in nature, prayer, meditation, inspirational literature, yoga, taking part in religious traditions or writing journals which is a core activity in all main spiritual and religious customs; (iii) Spirituality leadership with inner life or spiritual practice are more inclined to develop the other core values of altruistic love and service vision to main stakeholders and the faith to do what is needed for the realization of such a vision; (iv) consequentially, both leaders and followers will share sense of membership, that is based on level of spiritual well-being (SWB) that provides awareness of being understood and appreciated; (v) This implies that visions can be realized once based on faith and inclination to do what are needed; (vi) therefore, producing a sense of meaningful life that has meaning, purpose and can makes differences; (vii) thus justifying the fact that faith enables belief, conviction, trust and action in performing work catered towards achieving visions (Biberman \& Tischler, 2008).

In summary, the Spirituality brings forth that faith in the vision of the organisation's vision helps in maintaining the focus of followers on the future directions and generates the desire and positive expectation that drives effort through intrinsic motivation. This motivation cycle built on vision, altruistic love, and faith leads to increased SWB sense (calling and membership) and finally, positive individual and organisational results like commitment and productivity (Fry, 2003), employee life satisfaction, (Biberman \& Tischler, 2008; Fry, 2005) and with an effective market strategy, that leads to improved financial performance (Fry \& Matherly, 2007; Fry \& Matherly, 2006).

\section{Discussion and Conclusion}

In this paper, we have reviewed the incorporation spirituality into the BSC because an extensive focus is made by addressing the significance of non-financial predictors of financial performance, such as customer satisfaction, operating/internal measures, quality, leadership, innovation, and employee well-being and growth. Spirituality supports organizational performance as well as improved employees' performances and organizational effectiveness. Furthermore, the incorporation of the spirituality perspective may be as a necessary driver to employees' well-being, organizational commitment and productivity and, ultimately, financial performance of the organizations.

This paper presents a discussion on the potential contribution and influence of Spirituality on the BSC Financial Performance of in organisations. These are in line with a new paradigm shift of the effects of spirituality on employees' performance and effectiveness (Duchon \& Plowman, 2005; Fry et al., 2011; Fry et al., 2010). These studies have successfully confirmed a spiritual leadership causal model and its measures' for reliability and validity. Their results support a significant positive impact of spiritual leadership upon employee life satisfaction, organisational commitment, productivity and growth in sales (Biberman \& Tischler, 2008; Fry \& Matherly, 2007; Fry \& Matherly, 2006).

The Spirituality tendencies at workplaces therefore make the entire workplace to feel the existence and ordered universe that transcend human capabilities, that must be shared by the whole workforce and not necessarily with 
either the management alone or the employees. This is consequential to the behavior when the workforce in an organisation believes in the existence beyond this present form, while fulfilling the calling to life itself. These are tied to the interconnection to a very high power in respect to the relationship with human beings. This is centred on the need for humans to be mutually responsible to others, particularly, when there are dare needs to address such as misery and suffering, based on the conviction that that life is only worthwhile when it is lived in the services for others.

These deductions are also connected to the interconnection with nature and all living things. These are among the strong ties of spirituality with others connectedness and thus justifies the potential contribution to enhancing non financial performance on the BSC.

These connections are with respect to nature and mankind, as well as with other life forms. These are also in line with having the joy of being with all that exists around, as well as other living forms of nature. Consequently, these effects of Spirituality would be translated among the workforce and thereafter to the organisation's Financial- Performance, thereby enhancing the cause and effect relationships in the BSC.

\section{References}

Al-Zwyalif, I. M. (2012). The Possibility of Implementing Balanced Scorecard in Jordanian Private Universities. International Business Research, 5(11), 113. http://dx.doi.org/10.5539/ibr.v5n11p113

Anderson, P. (2000). This place hurts my spirit. Journal for Quality and Participation, 23(4), 16-17.

Ashmos, D., \& Duchon, D. (2000). Spirituality at work. Journal of management inquiry, 9(2), 134-145.

Bento, R. B., \& Lourdes, F. W. (2012). Validating Cause-and-Effect Relationships in the Balanced Scorecard. Cambridge Business \& Economics Conference.

Biberman, J., \& Tischler, L. (2008). Spirituality in business: theory, practice, and future directions. Palgrave Macmillan.

Biberman, J., \& Whitty, M. (1997). A postmodern spiritual future for work. Journal of Organizational Change Management, 10(2), 130-138. http://dx.doi.org/10.1108/09534819710160790

Biberman, J., Whitty, M., \& Robbins, L. (1999). Lessons from Oz: balance and wholeness in organizations. $\begin{array}{llll}\text { Journal of Organizational Change } & \text { Management, } & \text { 12(3), }\end{array}$ http://dx.doi.org/10.1108/09534819910274035

Bierly, P. E. III, Kessler, E. H., \& Christensen, E. W. (2000). Organizational learning, knowledge and wisdom. Journal of Organizational Change Management, 13(6), 595-618. http://dx.doi.org/10.1108/09534810010 378605

Bovet, D., \& Martha, J. (2000). Value nets: Breaking the supply chain to unlock hidden profits. John Wiley \& Sons.

Brophy, M. (2014). Spirituality Incorporated: Including Convergent Spiritual Values in Business. Journal of Business Ethics, 1-16. http://dx.doi.org/10.1007/s10551-014-2337-y

Brown, R. B. (2003). Organizational spirituality: The sceptic's version. Organization-London, 10(2), 393-400.

Burack, E. H. (1999). Spirituality in the workplace. Journal of Organizational Change Management, 12(4), 280-292. http://dx.doi.org/10.1108/09534819910282126

Capra, F. (1996). The Web of Life. Anchor Books. New York.

Cash, K. C., \& Gray, G. R. (2000). A framework for accommodating religion and spirituality in the workplace. The Academy of Management Executive, 14(3), 124-133. http://dx.doi.org/10.5465/AME.2000.4468072

Cavanagh, G. F. (1999). Spirituality for managers: context and critique. Journal of Organizational Change Management, 12(3), 186-199. http://dx.doi.org/10.1108/09534819910273793

Cavanagh, G. F., \& Bandsuch, M. R. (2002). Virtue as a benchmark for spirituality in business. Journal of Business Ethics, 38(1-2), 109-117. http://dx.doi.org/10.1023/A:1015721029457

Chen, Y.-F., Lee, S.-C., \& Mo, H.-E. (2012). Innovative Operation in A Private University Of Technology--An Application Of Strategy Map On Balanced Scorecard. International Journal of Asian Social Science, 2(11), 1877-1891.

Chuang, M. (2007). The Balanced Scorecard: Creating a management system for private technical universities in Taiwan. (3243815 Ed.D.), Spalding University, Kentucky, United States. Retrieved from 
https://vpn.utm.my/docview/304741860?accountid=41678ProQuestDissertations\&ThesesFullTextdatabase

Cohen, S., Thiraios, D., \& Kandilorou, M. (2008). Performance parameters interrelations from a balanced scorecard perspective: An analysis of Greek companies. Managerial Auditing Journal, 23(5), 485-503. http://dx.doi.org/10.1108/02686900810875307

Conger, J. A., \& Kanungo, R. N. (1988). The empowerment process: Integrating theory and practice. Academy of management review, 471-482. http://dx.doi.org/10.5465/AMR.1988.4306983

Cotton, J. L. (1993). Employee involvement: Methods for improving performance and work attitudes. Sage London.

Dean, K. L., Fornaciari, C. J., \& McGee, J. J. (2003). Research in spirituality, religion, and work: Walking the line between relevance and legitimacy. Journal of Organizational Change Management, 16(4), 378-395. http://dx.doi.org/10.1108/09534810310484145

Dehler, G. E., \& Welsh, M. A. (1994). Spirituality and organizational transformation: Implications for the new management paradigm. Journal of Managerial Psychology, 9(6), 17-26. http://dx.doi.org/10.1108/ 09534810310484145

Delbecq, A. L. (1999). Christian spirituality and contemporary business leadership. Journal of Organizational Change Management, 12(4), 345-354. http://dx.doi.org/10.1108/09534819910282180

Dent, E. B., Higgins, M. E., \& Wharff, D. M. (2005). Spirituality and leadership: An empirical review of definitions, distinctions, and embedded assumptions. The leadership quarterly, 16(5), 625-653. http://dx.doi.org/10.1016/j.leaqua.2005.07.002

Dooley, K. J. (1997). A complex adaptive systems model of organization change. Nonlinear dynamics, psychology, and life sciences, 1(1), 69-97. http://dx.doi.org/10.1023/A:1022375910940

Duchon, D., \& Plowman, D. A. (2005). Nurturing the spirit at work: Impact on work unit performance. The leadership quarterly, 16(5), 807-833. http://dx.doi.org/10.1016/j.leaqua.2005.07.008

Elm, D. R. (2003). Honesty, spirituality, and performance at work. Handbook of workplace spirituality and organizational performance, 277-288.

Fernando, M. (2005). Workplace spirituality: Another management fad?

Fornaciari, C. J., \& Dean, K. L. (2001). Making the quantum leap: Lessons from physics on studying spirituality and religion in organizations. Journal of Organizational Change Management, 14(4), 335-351. http://dx.doi.org/10.1108/EUM0000000005547

Fry, L. W. (2003). Toward a theory of spiritual leadership. The leadership quarterly, 14(6), 693-727. http://dx.doi.org/10.1016/j.leaqua.2003.09.001

Fry, L. W. (2005). Toward a theory of ethical and spiritual well-being, and corporate social responsibility through spiritual leadership. Positive psychology in business ethics and corporate responsibility, 47-83.

Fry, L. W., \& Matherly, L. (2007). Workplace spirituality, spiritual leadership and performance excellence. Encyclopedia of Industrial/Organizational Psychology (Sage Publications, San Francisco).

Fry, L. W., \& Matherly, L. L. (2006). Spiritual leadership and organizational performance: An exploratory study. Tarleton State University-Central Texas.

Fry, L. W., Hannah, S. T., Noel, M., \& Walumbwa, F. O. (2011). Impact of spiritual leadership on unit performance. The leadership quarterly, 22(2), 259-270. http://dx.doi.org/10.1016/j.leaqua.2011.02.002

Fry, L. W., Matherly, L. L., \& Ouimet, J. R. (2010). The spiritual leadership balanced scorecard business model: the case of the Cordon Bleu - Tomasso Corporation. Journal of Management, Spirituality and Religion, 7(4), 283-314. http://dx.doi.org/10.1080/14766086.2010.524983

Garcia-Zamor, J. C. (2003). Workplace spirituality and organizational performance. Public Administration Review, 63(3), 355-363. http://dx.doi.org/10.1111/1540-6210.00295

Giacalone, R., Jurkiewicz, C., \& Fry, L. W. (2005). From advocacy to science. The Psychology of Religion and Spirituality, 515-528.

Giacalone, R. A., \& Eylon, D. (2000). The Development of New Paradigm Values, Thinkers, and Business Initial Frameworks for a Changing Business Worldview. American Behavioral Scientist, 43(8), 1217-1230. http://dx.doi.org/10.1177/00027640021955838 
Giacalone, R. A., \& Jurkiewicz, C. L. (2003). Right from wrong: The influence of spirituality on perceptions of unethical business activities. Journal of Business Ethics, 46(1), 85-97. http://dx.doi.org/10.1023/A:1024767511458

Glaveli, N., \& Karassavidou, E. (2011). Exploring a possible route through which training affects organizational performance: the case of a Greek bank. The International Journal of Human Resource Management, 22(14), 2892-2923. http://dx.doi.org/10.1080/09585192.2011.606113

Gogoi, P. (2005). A little bit of corporate soul.

Gottlieb, B. H., Kelloway, E. K., \& Barham, E. J. (1998). Flexible work arrangements: Managing the work-family boundary: Wiley.

Harman, W. W., \& Hormann, J. (1990). Creative work: The constructive role of business in a transforming society. Knowledge Systems Indianapolis.

House, R. J., \& Shamir, B. (1993). Toward the integration of transformational, charismatic, and visionary theories. Leadership theory and research: Perspectives and directions, 81-107.

Howard, S. (2002). A spiritual perspective on learning in the workplace. Journal of Managerial Psychology, 17(3), 230-242. http://dx.doi.org/10.1108/02683940210423132

Hyman, J., \& Mason, B. (1995). Managing employee involvement and participation. SAGE Publications Limited.

Inglehart, R. (1997). Modernization and postmodernization: Cultural, economic, and political change in 43 societies (Vol. 19). Cambridge Univ Press.

Ittner, C. D., \& Larcker, D. F. (1998). Are nonfinancial measures leading indicators of financial performance? An analysis of customer satisfaction. Journal of accounting research, 36, 1-35.

Kaplan, R. S. (2004). Strategy maps: Converting intangible assets into tangible outcomes. Harvard Business Press.

Kaplan, R. S. (2012). The balanced scorecard: comments on balanced scorecard commentaries. Journal of Accounting and Organizational Change, 8(4), 539-545. http://dx.doi.org/10.1108/18325911211273527

Kaplan, R. S., \& Norton, D. (2004). Strategy Maps: Converting Intangible Assets into Tangible Outcomes. Boston, MA: Harvard Business School Press.

Kaplan, R. S., \& Norton, D. P. (1992). The balanced scorecard--measures that drive performance. Harvard business review, 70(1), 71-79.

Kaplan, R. S., \& Norton, D. P. (1996a). The balanced scorecard. Harvard Business School Press.

Kaplan, R. S., \& Norton, D. P. (1996b). Translating strategy introduction the balanced scorecard.

Kaplan, R. S., \& Norton, D. P. (2001a). The strategy-focused organization: How balanced scorecard companies thrive in the new business environment. Harvard Business Press.

Kaplan, R. S., \& Norton, D. P. (2001b). Transforming the balanced scorecard from performance measurement to strategic management: Part I. Accounting horizons, 15(1), 87-104. http://dx.doi.org/10.2308/acch.2001.15.1.87

Kaplan, R. S., \& Norton, D. P. (2005). Creating the Office of Strategy Management. Division of Research, Harvard Business School.

Karakas, F. (2010). Spirituality and performance in organizations: A literature review. Journal of Business Ethics, 94(1), 89-106. http://dx.doi.org/10.1007/s10551-009-0251-5

Karun, P., \& Pilaipan, C. (2011). The impact of strategy for building sustainability on performance of software development business in Thailand. Asian J. Bus. Management, 3, 32-39.

Konz, G. N., \& Ryan, F. X. (1999). Maintaining an organizational spirituality: No easy task. Journal of Organizational Change Management, 12(3), 200-210. http://dx.doi.org/10.1108/09534819910273865

Korac-Kakabadse, N., Kouzmin, A., \& Kakabadse, A. (2002). Spirituality and leadership praxis. Journal of Managerial Psychology, 17(3), 165-182. http://dx.doi.org/10.1108/02683940210423079

Kriger, M. P., \& Hanson, B. J. (1999). A value-based paradigm for creating truly healthy organizations. Journal of Organizational Change Management, 12(4), 302-317. http://dx.doi.org/10.1108/09534819910282144 
Kugelmass, J. (1995). Telecommuting: A manager's guide to flexible work arrangements. Lexington books New York.

Lewin, R. (1992). Complexity: Life at the edge of chaos. Macmillan Pub. Co. (New York and Toronto and New York).

Li, W. (2011). Performance evaluation for private colleges and universities based on the balanced scorecard. Paper presented at the Management Science and Industrial Engineering (MSIE), 2011 International Conference on. http://dx.doi.org/10.1109/MSIE.2011.5707480

Lips-Wiersma, M. (2003). Making conscious choices in doing research on workplace spirituality: Utilizing the "holistic development model" to articulate values, assumptions and dogmas of the knower. Journal of Organizational Change Management, 16(4), 406-425. http://dx.doi.org/10.1108/09534810310484163

Maddock, R. C., \& Fulton, R. L. (1998). Motivation, emotions, and leadership: The silent side of management. Praeger Pub Text.

Mirvis, P. H. (1997). " Soul Work" in Organizations. Organization Science, 193-206.

Mitroff, I. I., \& Denton, E. A. (1999). A study of spirituality in the workplace. Sloan management review, 40(4), 83-92.

Neck, C. P., \& Milliman, J. F. (1994). Thought self-leadership: Finding spiritual fulfilment in organizational life. Journal of Managerial Psychology, 9(6), 9-16. http://dx.doi.org/10.1108/02683949410070151

Niven, P. R. (2005). Balanced scorecard diagnostics: Maintaining maximum performance. John Wiley \& Sons.

Niven, P. R. (2011). Balanced scorecard: Step-by-step for government and nonprofit agencies. Wiley.

Park, J. A., \& Gagnon, G. B. (2006). A causal relationship between the balanced scorecard perspectives. Journal of Human Resources in Hospitality \& Tourism, 5(2), 91-116. http://dx.doi.org/10.1300/J171v05n02_06

Pratoom, K., \& Cheangphaisarn, P. (2011). The Impact of Strategy for Building Sustainability on Performance of Software Development Business in Thailand. Asian Journal of Business Management, 3(1), 32-39.

Ramli, M. (2006). Hadhari Scorecard. Paper presented at the Proceeding. Seminar on Islamic Accounting and Balanced Scorecard: Myth or Reality.

Ray, M., \& Rinzler, A. (1993). The new paradigm in business: emerging strategies in leadership and organisational change. World Business Academy. New York: Tarcher/Perigee.

Reder, M. W. (1982). Chicago economics: permanence and change. Journal of economic literature, 20(1), 1-38.

Rigby, D. (2001). Management tools and techniques: A survey. California management review, 43(2), 139-160.

Tejeda, M. J. (2014). Exploring the Supportive Effects of Spiritual Well-Being on Job Satisfaction Given Adverse Work Conditions. Journal of Business Ethics, 1-9. http://dx.doi.org/10.1007/s10551-014-2269-6

Thompson, C. M. (2000). The congruent life: Following the inward path to fulfilling work and inspired leadership. Jossey-Bass San Francisco.

Tischler, L. (1999). The growing interest in spirituality in business: A long-term socio-economic explanation. Journal of Organizational Change Management, 12(4), 273-280.

Turner, J. (1999). REGULARS-CONTROL-Ethics-Spirituality in the workplace. CA Magazine-Chartered Accountant, 132(10), 41-42.

Wagner-Marsh, F., \& Conley, J. (1999). The fourth wave: The spiritually-based firm. Journal of Organizational Change Management, 12(4), 292-302.

Wheatley, M. (1992). Leadership and the new science: Learning about organizations from an orderly universe. San Francisco: Berrett-Koehler.

\section{Copyrights}

Copyright for this article is retained by the author(s), with first publication rights granted to the journal.

This is an open-access article distributed under the terms and conditions of the Creative Commons Attribution license (http://creativecommons.org/licenses/by/3.0/). 